\title{
PROFESSIONALISM
}

ISSN: 1893-1049

Volume 10 , No 3 (2020), e3838

\section{Constructions of Vulnerability by Different Groups of Welfare Professionals}

\section{Birgitte Theilmann ${ }^{1} \&$ Erik Laursen ${ }^{2}$}

1. Aalborg University, Denmark

2. Aalborg University, Denmark

Contact: Birgitte Theilmann, Aalborg University, birgittetheilmann@yahoo.dk

\section{Abstract}

This article has examined the various ways vulnerability among children is constructed by four groups of welfare professionals (teachers, daycare workers, social workers, and health care workers) within a Danish welfare context. Based on an empirical research project that featured a large number of interviews, the article has demonstrated how professionals construct vulnerability from a combination of their professional background and experiences in their working practice related to vulnerability among children. The research findings have revealed that professional employees in general tend to link vulnerability among children to either diagnoses and deviant behavior or a child's family context. At the same time, professional employees tend to ignore the possibility that vulnerability might be produced inside an institutional context like a school or kindergarten. In linking vulnerability to the child's family context, professional employees generally point to classic forms of risk and social problem factors related to children's families.

\section{Keywords}

Vulnerable children, social work, interdisciplinary cooperation 


\section{Introduction}

Over the past couple of decades, Denmark has paid increased attention to children in vulnerable positions. As a result, there has been a considerable political will to propose and implement social reforms intended to reduce the proportion of children in vulnerable positions or at least reduce their levels of vulnerability (Socialstyrelsen, 2011). Recent studies have revealed that, despite this vigilance, the share of Danish children in vulnerable positions is actually increasing (Danmarks Statistik, 2018; National Association of Municipalities, 2019). A strong political focus on vulnerability, combined with reforms and interventions, is also reflected in a more global context, often without achieving the desired goal. This is especially true of preventive strategies targeting vulnerable children, which has been a major emphasis in many European countries (Eurochild, 2016, 2017; European Commission, 2013). In spite of this strengthened legislative focus, the strategies adopted do not appear to be working, as only modest improvements in the share of children facing social problems and vulnerabilities have been reported (Cingano, 2014; Inchley \& Currie, 2016). Several studies have focused on implementation, focusing on the role of professional employees (Bo, Guldager, \& Zeeberg, 2015; Brodkin, 2012; Lipsky, 2010; Zacka, 2017). However, there has not been a corresponding focus on how vulnerability among children has been conceptualized. The existing literature reveals a consensus about defining children in vulnerable positions from a variety of dimensions: poverty, social exclusion, violence, sexual abuse, health difficulties, stigmatization, and discrimination (Andersen, Jensen, Nielsen, \& Skaksen, 2017; House of Commons, 2008; Mynarska et al., 2015). In general, there has been less focus on identifying children with a more privileged social background who show symptoms of lacking well-being, but there is now growing interest in expanding traditional ways of delineating vulnerability. This implies that when vulnerability is to be detected by professional employees, they must examine broader target groups (Görlich et al., 2019). To be able to target social efforts to specific groups of children in vulnerable positions, it is necessary to identify and classify those groups and link this classification to the different kinds of efforts directed at them by the social welfare apparatus. This study investigates how different groups of welfare professionals construct vulnerability among children and seeks to answer this research question: How do different groups of welfare professionals (teachers, daycare workers, social workers, and health care workers) construct vulnerability when defining the target group for interventions and special efforts? This question requires investigating both how constructions are actually carried out and the results of those processes of construction. Finally, we strive to identify factors affecting the processes of construction.

\section{The case}

As a study case, we use the implementation of a developmental strategy in the area of vulnerable children in Aalborg, a large Danish municipality, from 2016 to 2020 (Commune of Aalborg, 2016). The strategy relates to Aalborg's school administration and its family and 
employment (F\&E) administration. Cooperation between the two administrations addresses early detection and preventive work with vulnerable children. The strategy addresses two target groups: children showing initial signs of a lack of well-being who are at risk of later developing special needs, and children who are exposed to serious threats and in obvious danger of permanent damage. Cooperation between the employees in the organizations involves developing a common understanding of both target groups, which is a prerequisite for interdisciplinary cooperation between the professions involved. This is especially true for the four professional groups most central to vulnerable children. At the same time, those four professional groups work in different areas; while teachers, daycare workers, and health care workers deal with the general public, social workers serve a specialized population. There are also different work tasks: teaching (teachers), teaching and care (daycare workers), guidance (health care workers), and social efforts (social workers).

\section{Research design and methods}

In order to examine the construction of vulnerability among welfare professionals within the organizations, we conducted semi-structured individual interviews with four teachers, four social workers, three daycare workers, and four health care workers (4). We also conducted group interviews based on cases with the same informant groups-three teachers, three social workers, two daycare workers, and three health care workers - to initiate discussions about vulnerability within the groups. Altogether, 72 welfare professionals were interviewed.

The interview guide used for the individual interviews included wide-ranging and openended questions that focused more on theme than fine detail. The themes were 1) target group descriptions, 2) organizing interdisciplinary cooperation, 3) options for action, and 4) professional knowledge. These themes were also elements of the cases used in the group interviews. The interviews were coded using the NVivo software package. The process of coding comprised two levels: first, a broader thematic coding according to key concepts in the strategy (vulnerable children, interdisciplinary cooperation, early intervention and prevention, and organizational and professional knowledge), and then a more focused coding containing the key theoretical concepts derived from Abbott's (1988) notions of jurisdiction and diagnosis, inference, and treatment. The coding contained statements from the professionals according to their tasks and their attitudes toward vulnerability, which were clustered into categories. For analytical purposes, we used power and proof quotes (Pratt, 2008) to illustrate and pinpoint important findings and key understandings. Power quotes are strong opinions and statements from interviewees that capture the central messages of the analysis. Proof quotes are several short single quotes, puzzle pieces that contribute to the overall analysis. The proof quotes are presented in two meaningcondensed tables below (Pratt, 2008). 
The structure of the analysis unfolds in two stages. The first part examines theoretical perspectives on vulnerability by analyzing the symptoms and causes linked to vulnerability, how welfare professionals define and construct vulnerability, and individual and contextual stresses. The second part examines the types of knowledge influencing the construction of vulnerability among welfare professionals and their professional backgrounds and functions.

Based on our findings, we reflect on the consequences of ways of constructing vulnerability in regard to both the contextual practice of different interventions and interdisciplinary cooperation. Finally, we summarize the article's key points, followed by our closing reflections on welfare professionals' different constructions of vulnerability.

\section{Abbott's key concepts of jurisdiction and diagnosis, inference, and treatment}

In our analysis of the similarities and differences in the four groups of professions, we use Abbott's (1988) theoretical framework and his notion of jurisdiction, buttressed by the key concepts of diagnosis, inference, and treatment. Our aim is to understand the extent to which and why constructions of vulnerability made by the professionals are influenced by their organizational positions, their professional tasks, and their professional backgrounds.

For Abbott, jurisdiction refers to the legitimate requirements for certain workers to maintain their specialized expertise and related competences. For that purpose, each profession builds a knowledge system (Abbott, 1988), which-in addition to academic expert knowledge-consists of more practical and experience-based cognitive procedures for problem identification (diagnoses) and problem intervention (treatment). According to Abbott, the understanding of the construction of professional jurisdiction includes-besides language-embodied experiences, material working tools, and organizational arrangements. However, language is central, as Abbott's concepts of the knowledge system refer to a great extent to how certain expertise and understandings of diagnosis and intervention are codified linguistically as common professional resources. Each profession must balance different linguistic forms that relate to academic and practical working contexts. This point is particularly relevant for an analysis of the constructions of vulnerability among different professional groups.

In Abbott's understanding, diagnosis, inference, and treatment constitute three interconnected moments in practical professional work and are thus an approach to the notion of professional discretion ( $\varnothing$ stergaard Møller, 2018). Abbott uses these terms in a general way to understand the work of the professions. In our case, this includes the different ways vulnerability is constructed and identified (diagnosis) and explained and handled professionally through social and pedagogical interventions (treatment). Fundamentally, presenting a professional diagnosis is a question of how a given profession classifies, designates, and distinguishes a problem as a problem of expertise, while 
treatment is about how professions address problems by choosing relevant types of interventions to undertake. Inference is the process that connects these two moments, linking the general classification of a problem with a specific type of intervention adapted to the specific case of a particular child.

\section{Constructing vulnerability as a combination of protection and risks}

Catalano, Berglund, Ryan, Lonczak \& Hawkins (2002) pointed out that promising preventive efforts and early interventions are based on knowledge about risk and protective factors, but they also called for new research addressing the dynamics between risk and protective factors.

According to Kvello (2013), risk factors are common terms describing conditions that increase the probability of developing problems when growing up in families with one or more challenges. Some risk factors are closely connected to the development of specific problems, while others are related to many different disorders. Just as it is the continuous interaction between child and environment that influences children the most, it is also longlasting exposure to risk factors that has the most severe effects on children, as opposed to shorter periods of intense exposure to high-risk factors (Kvello, 2013). Conversely, there are several protective factors in the childhood environment or within the individual that reduce the probability of damaging effects on children who are exposed to risk factors (Kvello, 2013). Like risk factors, protective factors include genetic, biological, mental, environmental, and social aspects (Schoon, 2006). Protective factors can be effective against several risk factors and become crucial when risk factors are severe because they have been present for a lengthy period.

Risk and protective factors can be both static and dynamic. The former are genetic predisposition, gender, and other factors that can only be altered to a modest extent, if at all, by social interventions. More often, risk and protective factors are dynamic and susceptible to influence and change through such interventions (Kvello, 2013).

A mapping of risk and protective factors for children in vulnerable families conducted by Rambøll Management Consulting (2016) shows-across 70 international and 15 Nordic studies - that factors apart from parental care can affect the development of a child. Personal, individual, familial, and contextual relationships can all be either protective or risk factors for different target groups among children who live in families with social problems. For this reason, knowledge about protective and risk factors is important for professional employees working with vulnerable children, as they can connect to the children through relationships in an institutional context.

According to the Rambøll study (2016), risk and protective factors that influence mental difficulties can be divided into the following three domains: 1 ) individual factors attached to 
the child's own resilience; (2) familial factors connected to the home environment, parenting skills, parenting interactions with the child, and proximity of relation; and (3) institutional factors related to the contextual surroundings that constitute the child's network.

\section{Analysis of symptoms and causes linked to vulnerability}

\section{Symptoms, causes, and consequences}

Because of how the concept is constructed, the academic field of children in vulnerable positions is associated with a multitude of terms and notions that fall into two broad categories: factors that burden children's everyday lives and symptoms, signs, or indicators of the different kinds of burdens to which children are exposed (Görlich et al., 2019). The competences to make valid interpretations of the various indicators of possible situations of vulnerability and thus detect the largely hidden sources that are creating discomfort and stress make up an important part of the professional role of employees working in this field. The method that welfare professionals choose to solve the problem depends on how vulnerability considered as a problem is constructed, experienced, and explained (Abbott, 1988). Definitions are used by the professionals to identify and categorize children in vulnerable positions and thus make target groups for different kinds of efforts by the welfare sector.

The overall construction of vulnerability refers to three elements: the signs, indicators, or symptoms of vulnerability, the causes of vulnerability, and the consequences of vulnerability. It is largely signs and causes that make up the definition of vulnerability, along with its delineation from other phenomena. While indicators constitute the immediately observable phenomena of vulnerability, causes are typically more difficult to identify. They often require additional information in order to detect with accuracy the hidden factors producing the symptoms and, through professional analysis, to explain the relationships between causes and symptoms and point toward the proper ways of intervening in a situation. Concerns arise based on observed indicators that are either verified or rebutted based on whether an underlying cause can be detected and confirmed. Finally, the consequences of vulnerability are used to distinguish between different types and levels of vulnerability.

The classified phenomena are grouped together with other phenomena that appear to have significant common features. The category of vulnerability is further differentiated into a number of subcategories, each of which is different enough to merit a categorical distinction (Lakoff, 1987; Laursen, 2020). 


\section{The who, why, and how of classifying vulnerability}

To support the analytical framing of the ways that employees in welfare organizations classify human beings, Rubington and Weinberg (1969) suggested the set of questions detailed in the paragraphs below.

Who defines and classifies whom? Definitions and classifications are attached to children who show worrying features indicating that they are in vulnerable positions: violent behavior, self-harming behavior, absence from school, stress and anxiety, and a lack of participation in social communities. Definitions and classifications also include the children's families as factors, because risk-creating stresses are often located in the family; examples include violence, abuse, changes in the behavior of the child due to parental discord and career parents who are busy and do not have time for their children. The institutional context of kindergarten or school is, however, also involved, especially as a framework in which symptoms of vulnerability can be observed. Definitions and classifications are carried out by a number of professionals within the two administrations.

Why do people make definitions and classifications? Because public organizations are part of a welfare society with an imperative to act on social problems. According to Bacchi (2009), a phenomenon like vulnerability becomes a problem when society perceives it as such and feels a responsibility to address it. The starting point is to perceive it against the background of desirable normality, according to which it is possible to construct anomaly, its undesirable counterpoint. Based on a concept of normality, various examples of a lack of well-being are defined as abnormal and are thus conditions that will permanently harm the child. This motivates a morally justified demand to intervene in the problem.

In order to reduce the level of vulnerability among children, employees in both administrations are asked to identify signs and indicators of children's being at risk and to provide a description of the situation. In order to create a precise and informative description, professionals need to distinguish between different levels of vulnerability by estimating how serious the risks are. This classification is used to select the proper kind of intervention from among the options available in the two administrations (Jenkins,1996; Laursen, 2020; Theilmann, 2020).

Even though all professionals share the same goal of early detection of vulnerable children, they are also each influenced by their different tasks. In practice, they classify according to slightly different criteria, depending on the particular purpose of their profession in classifying vulnerability. The social workers connect vulnerability to family background, where violation, abuse, mental illness, and a lack of resources are the most prominent factors, although diagnoses of children and recurring absences from school are also involved. The teachers focus on children who deviate from ideal pupils, who are 
independent, self-reflexive, and responsible for their own learning processes. Daycare workers are generally aware of children's access to and participation in social relationships, and health care workers focus on physical (mal)development and psychological well-being (Theilmann, 2020). Employees in the general area (teachers and daycare workers) initially make classifications from the perspective where daily operations like teaching and care are carried out. Disturbances and problems in daily operations are therefore classified according to a desire to keep operations flowing, which can lead to employees focusing on well-being in a broader sense.

How can this be done? The identifications and classifications carried out in relation to vulnerability are an integrated part of the general process of identifying, explaining, and intervening in problems; as moments in the professional work process, they are carried out with support from the individual's profession (Abbott, 1988; Østergaard M $\varnothing l l e r, 2018$ ). The knowledge systems of the professions are generated from at least two sources: 1) professional training and 2) the work-based experience of individual professional employees. Employees draw on a broad knowledge base that describes and explains the phenomenon and on a set of procedures that prescribe how action should be undertaken (Argyris, 1992; Laursen, 2020).

Through the interviews in our study, we learned that the professional groups draw on different sources of information. Social workers collect assessments from colleagues with different professional backgrounds:

"When I receive a referral, I am always careful about the fact that many explanations can be at play. I often involve the kindergarten to qualify my decisions" (Social Worker (SW) 2).

Teachers generally refer to their own knowledge constructions and self-made models. Still, technologies are also used as a tool for communicating with employees from other professions and administrations:

"I make my own models in accordance with my experience, but sometimes the social workers ask me for a school statement. Then I use the ICS model" (Teacher (T) 1).

Daycare workers take a more multifaceted approach to knowledge and methods. When revealing their understanding of a problem, they draw on knowledge from the child's family and their colleagues, combined with professional discussions with other cooperators, handbooks, methods, models, and theories. For example, daycare worker (DCW) 1 reports the following: "I use Børnelinealen [an assessment tool] to make the relevant determinations." DCW 2, meanwhile, says her professional group uses "the three perspectives of in front, next to, and behind the child to reach the nearest development" to qualify the identification and classification problems and as a prerequisite for initiating interventions. Health care workers report navigating between emotions, moods, 
professional intuitions, and their prior understanding of good growth, relying on their nursing background to understand the well-being of the child as a starting point for professional decisions and interventions (Theilmann, 2020).

\section{How welfare professionals define vulnerability}

All interviewed employees were asked how they defined children in vulnerable positions and thus demarcated them from other children. During the process of analysis, all answers were coded in NVivo into eight categories (see Table 1).

Table 1: Categorization (Theilmann \& Laursen, 2020)

\begin{tabular}{|c|c|c|c|c|}
\hline $\begin{array}{l}\text { Category/ } \\
\text { Professional group }\end{array}$ & Social workers & Teachers & Day care workers & $\begin{array}{l}\text { Health care } \\
\text { workers }\end{array}$ \\
\hline $\begin{array}{l}\text { Traditional social } \\
\text { problems }\end{array}$ & $\begin{array}{l}\text {-violation } \\
\text {-abusive parents } \\
\text {-mentally ill parents } \\
\text {-violent behavior } \\
\text {-substance abuse } \\
\text {-lack of resources in the } \\
\text { family } \\
\text {-parents with low IQ }\end{array}$ & $\begin{array}{l}\text {-children with only one } \\
\text { parent } \\
\text {-children with diagnoses } \\
\text {-traumatized children } \\
\text {-abusive families and } \\
\text { problematic divorces } \\
\text {-children from chaotic } \\
\text { homes }\end{array}$ & $\begin{array}{l}\text {-children not guided by } \\
\text { their parents } \\
\text {-unwashed and dirty } \\
\text { children } \\
\text {-concerns about family- } \\
\text { related issues } \\
\text {-children who have been } \\
\text { exposed to incest, } \\
\text { violence, or } \\
\text { misguidedness }\end{array}$ & $\begin{array}{l}\text {-no contact with parents } \\
\text {-resistance from parents } \\
\text { to professionals } \\
\text {-parents with diagnoses } \\
\text { and drug abuse } \\
\text {-conflicts at home } \\
\text {-quarreling parents } \\
\text {-vulnerable families, e.g., } \\
\text { low-income families or } \\
\text { ethnic families } \\
\text {-alcohol and violence }\end{array}$ \\
\hline $\begin{array}{l}\text { Physical and mental } \\
\text { handicaps }\end{array}$ & -children with diagnoses & & & $\begin{array}{l}\text {-difficulties when } \\
\text { regulating sleep and food } \\
\text { maldevelopment } \\
\text {-lacking contact with the } \\
\text { child } \\
\text {-physical problems } \\
\text {-overweight }\end{array}$ \\
\hline $\begin{array}{l}\text { Problems associated } \\
\text { with learning, skills, }\end{array}$ & -absence from school & $\begin{array}{l}\text {-children who are not } \\
\text { able to help themselves }\end{array}$ & $\begin{array}{l}\text {-children with difficulties } \\
\text { concentrating }\end{array}$ & $\begin{array}{l}\text {-child's development, } \\
\text { contact, interplay, and }\end{array}$ \\
\hline
\end{tabular}




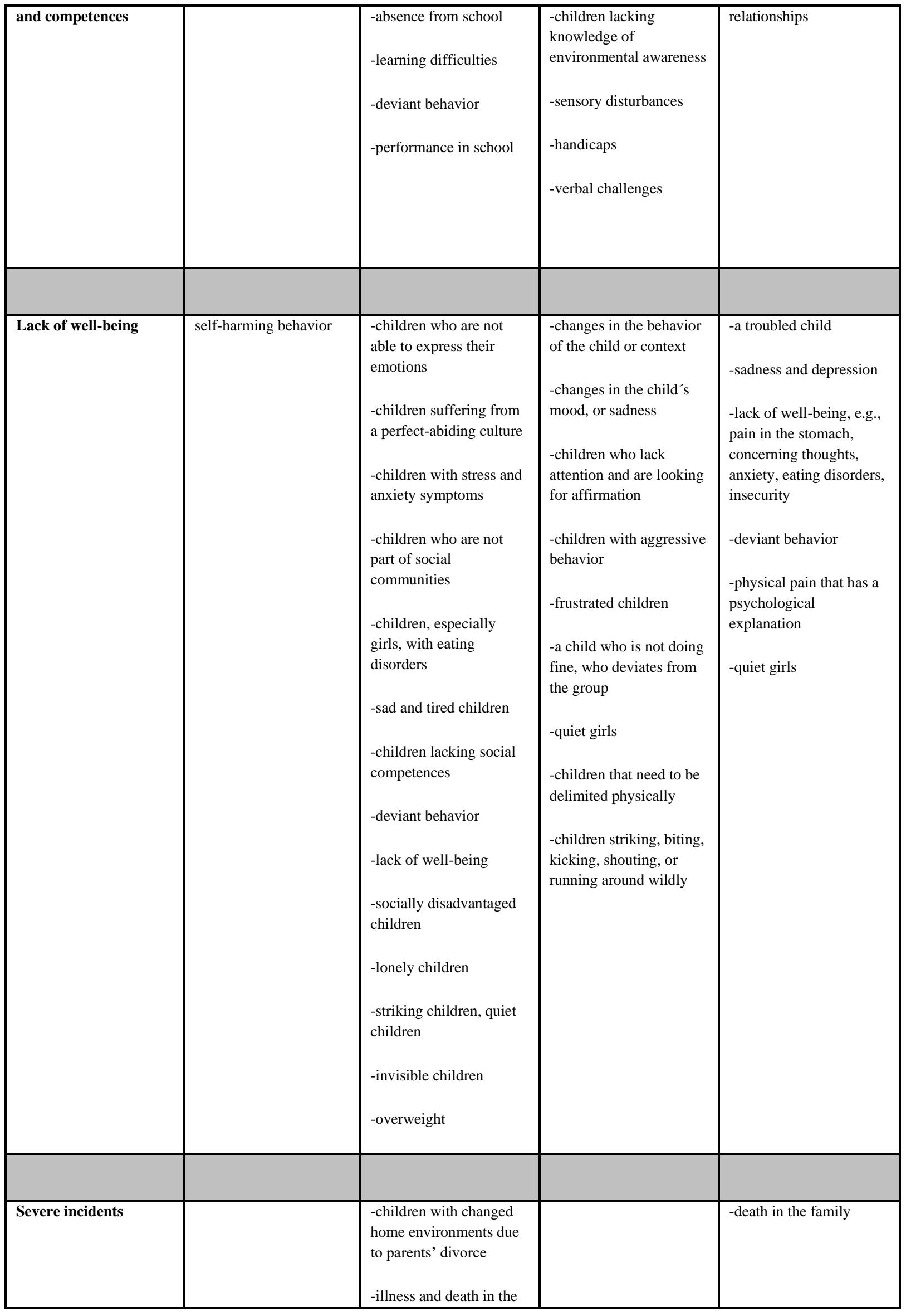




\begin{tabular}{|c|c|c|c|}
\hline & family & & \\
\hline $\begin{array}{l}\text { Stressful features } \\
\text { related to parents }\end{array}$ & $\begin{array}{l}\text {-busy parents who can } \\
\text { afford to hide problems } \\
\text { due to their finances } \\
\text {-lack of care from } \\
\text { parents in spite of } \\
\text { material goods } \\
\text {-parents who are busy } \\
\text { realizing themselves } \\
\text { through sports, new } \\
\text { relationships, etc. }\end{array}$ & $\begin{array}{l}\text {-career parents who are } \\
\text { busy and do not have } \\
\text { time for their children }\end{array}$ & \\
\hline Ethnic affiliation & -language-poor children & $\begin{array}{l}\text {-bilingual children who } \\
\text { are far behind in } \\
\text { language development }\end{array}$ & \\
\hline $\begin{array}{l}\text { Prematurity of the } \\
\text { child }\end{array}$ & & & $\begin{array}{l}\text {-prematurely born } \\
\text { children }\end{array}$ \\
\hline
\end{tabular}

In particular, there appears to be consistency in regarding traditional social problems in the child's family as an important cause of vulnerability. Other examples of overlap are physical or mental handicaps like ADHD and autism combined with children showing a lack of wellbeing. Ethnicity and premature birth were also commonly cited. These examples of consensus reflect a heavy emphasis on these factors in both public debate and research in the field (Andersen et al., 2017; Mynarska et al., 2015).

The professional employees, however, also refer to other understandings that deviate from the traditional approach to vulnerability. This is shown through the following categories: 1) problems associated with learning, skills, and competences; 2) severe incidents; and 3) stressful features related to parents as the third issue. Finally, the lack of well-being category is also relevant because that category contains an ambiguity that we explore below.

\section{Problems associated with learning, skills, and competences}

Learning, healthy development, and acquisition of competences are both causes and symptoms of vulnerability and phenomena that arise in the relationship between a child and 
the school or daycare. A child with learning problems in mathematics is not necessarily in a vulnerable position before encountering that subject and the learning goals associated with it. It does not necessarily represent a problem that a child has difficulties in achieving mathematical competences, but to understand vulnerability as something that might be produced in the institutional context is beyond a teacher's perspective if that vulnerability is either created in the private sphere and brought into the institutional context or is something inherent in the child. The same applies to the child in a kindergarten whose behavioral interactions with other children and adults are only recognized as problematic when observed in the institutional context.

\section{Severe incidents (divorce, illness, death)}

As shown above, the employees referred to severe incidents as factors stressing the child. Divorce, illness, and death affect anyone, regardless of status. This is thus a rupture with the conception of classic social problems as the all-encompassing risk factor. In this case, professional employees look beyond the classic approach to vulnerability and point to causes that make vulnerability relevant to other groups.

\section{Stressful features related to parents}

In real-world contexts, professional employees recognize different indicators when inferring vulnerability. Stressful factors can be recognized as both the more classic risk factors for vulnerability, such as unemployment in a certain demographic area, and as issues connected to welfare-oriented relationships, such as stress due to careerist, self-centered, and selfactualizing parents who focus on work and do not pay sufficient attention to their children's well-being. Teachers and daycare workers were especially likely to highlight this welfare problem as an explanation of vulnerability.

\section{Lack of well-being (loneliness, social isolation, conflicts)}

We emphasize that showing signs of a lack of well-being as a category both as belonging to the classic understanding of targets for early detection of vulnerability and as deviating from the classic understanding of vulnerability because of the professional employees' highlighting of loneliness, social isolation, and conflicts as issues that come into play for children in more privileged families. The empirical data also reveals an important insight; the powerful influence of classic understandings of vulnerability means that the same symptoms of vulnerability are not recognized as equally serious in more privileged families as in families with traditional symptoms of vulnerability. This is reflected by teachers and daycare workers stating that they do not have any children in vulnerable positions in their area and that vulnerability is attached to children in other areas in the commune: "We don't have this kind of children here" (DCW 4). One explanation for this view is that professional employees might consider privileged families to be carriers of multiple protective factors, which could cause them to disregard vulnerability among children in those families and/or believe that those children have the resources to meet challenges without intervention. Thus, these children are in a position where there is no particular concern for them. On the 
one hand, professional employees recognize the great variety in understandings of vulnerability, including which indicators ought to be observed. On the other, they find it easier to identify and act on the classic risk factors that constitute vulnerability.

Generally, social workers carry out their identifications and classifications related to vulnerability without the benefit of direct contact with the child in the detection phase. Instead, they receive reports of concern from other professionals involved with the child. Unlike social workers, teachers know the children well and spend time with them on a daily basis; therefore, they are less dependent on other professional assessments in the early detection phase. At the same time, teachers often have only limited insight into a child's family situation. In interpreting a situation that might cause concern, they draw on their previous personal experiences regarding possible interventions. Like the teachers, the daycare workers know the children well; in addition, they generally work more closely with the parents. Health care workers only meet children in a particular context: either a rare home visit or in school through a specific program. Health care workers thus make their assessments on the basis of nursing optics, which focuses on development vs. maldevelopment, health vs. disease, and normality vs. deviation. On the other hand, their jobs provide them with legitimate and accepted access to homes and thus to children's family situations.

\section{Individual and contextual stresses}

The professional employees made further distinguished between individual and contextual stresses and signs of a lack of well-being. Individual stresses are either something inherent in the child, like a diagnosis, or deviant behavior by the child. Contextual stresses related to the conditions around the child can involve both the familial context and the institutional context.

The study's empirical data shows that employees regard individual stresses as either behavioral modes of reaction or traces of personality. Regarding contextual features, the professional employees also distinguish between the institutional context and the familial context. In connection with contextual stresses there is a pronounced tendency among professional employees to consider only the family as a context that causes vulnerability. By contrast, there is a tendency for professionals to treat the school or kindergarten as an arena where individual traits attached to the child are viewed as causes of vulnerability, with the institutional context left unexamined as a causal factor.

Table 2: Origination of vulnerability, Theilmann \& Laursen, 2020

\begin{tabular}{|c|c|c|c|c|}
\hline $\begin{array}{l}\text { Origination/ } \\
\text { Professional group }\end{array}$ & Social workers & Teachers & Daycare workers & $\begin{array}{l}\text { Health care } \\
\text { workers }\end{array}$ \\
\hline & & & & \\
\hline
\end{tabular}




\begin{tabular}{|c|c|c|c|c|}
\hline $\begin{array}{l}\text { Personal traits attached } \\
\text { to the child }\end{array}$ & $\begin{array}{l}\text {-self-harming behavior } \\
\text {-violent behavior } \\
\text {-children with diagnoses }\end{array}$ & $\begin{array}{l}\text {-children who are not } \\
\text { able to help themselves } \\
\text {-language-poor children } \\
\text {-learning difficulties } \\
\text {-children who are not } \\
\text { able to express their } \\
\text { emotions } \\
\text {-children suffering from } \\
\text { a perfect-abiding culture } \\
\text {-children with stress and } \\
\text { anxiety symptoms } \\
\text {-children who are not a } \\
\text { part of social } \\
\text { communities } \\
\text {-eating disorders } \\
\text {-sad and tired children } \\
\text {-overweight } \\
\text {-striking children, quiet } \\
\text { children } \\
\text {-deviant behavior } \\
\text {-socially disadvantaged } \\
\text {-children } \\
\text {-children with diagnoses } \\
\text {-children lacking social } \\
\text { competences } \\
\text {-lack well-being } \\
\text { - }\end{array}$ & $\begin{array}{l}\text {-changes in the behavior } \\
\text { of the child or changes } \\
\text { around the child } \\
\text { - sadness or changes in } \\
\text { the child's mood } \\
\text {-bilingual children who } \\
\text { are far behind in } \\
\text { language development } \\
\text {-children with difficulties } \\
\text { concentrating } \\
\text {-children lacking } \\
\text { knowledge of } \\
\text { environmental awareness } \\
\text {-sensory disturbances } \\
\text {-children with aggressive } \\
\text { behavior } \\
\text {-frustrated children } \\
\text {-a child who is not doing } \\
\text { fine; one who deviates } \\
\text { from the group } \\
\text {-quiet girls } \\
\text {-children that need to be } \\
\text {-chimitdren striking, biting, } \\
\text { kicking }\end{array}$ & $\begin{array}{l}\text {-a troubled child } \\
\text {-difficulties in regulating } \\
\text { sleep and food } \\
\text {-the child's development, } \\
\text { contact, interplay, and } \\
\text { relationships } \\
\text {-physical mal- } \\
\text { development } \\
\text {-lacking contact with the } \\
\text { child } \\
\text {-prematurely born } \\
\text { children } \\
\text {-sadness and depression } \\
\text {-lack of well-being, e.g., } \\
\text { pain in the stomach, } \\
\text { concerning thoughts, } \\
\text { anxiety, eating disorders, } \\
\text { insecurity } \\
\text {-physical pain that has a } \\
\text { psychological } \\
\text { explanation } \\
\text {-quiet girls } \\
\text {-overweight }\end{array}$ \\
\hline Familial context & $\begin{array}{l}\text {-violation by parents } \\
\text {-abusive parents } \\
\text {-mentally ill parents } \\
\text {-substance abuse by } \\
\text { parents } \\
\text {-lack of resources in the }\end{array}$ & $\begin{array}{l}\text {-absence from school } \\
\text {-busy parents who can } \\
\text { afford to hide problems } \\
\text { thanks to their finances } \\
\text {-children with only one } \\
\text { parent } \\
\text {-lack of care from }\end{array}$ & $\begin{array}{l}\text {-changes in the behavior } \\
\text { of the child or changes } \\
\text { around the child } \\
\text {-children not guided by } \\
\text { their parents } \\
\text {-unwashed and dirty } \\
\text { children }\end{array}$ & $\begin{array}{l}\text {-no contact with parents } \\
\text {-family background: } \\
\text { violent parents, family } \\
\text { drug abuse, parents who } \\
\text { were placed in care } \\
\text {-resistance from parents } \\
\text { to professionals }\end{array}$ \\
\hline
\end{tabular}




\begin{tabular}{|c|c|c|c|c|}
\hline & $\begin{array}{l}\text { family } \\
\text {-parents with low IQ } \\
\text {-absence from school }\end{array}$ & $\begin{array}{l}\text { parents in spite of } \\
\text { material goods } \\
\text {-parents who are busy } \\
\text { realizing themselves } \\
\text { through sports, new } \\
\text { relationships, etc. } \\
\text {-children whose home } \\
\text { environment changed } \\
\text { due to parents' divorce } \\
\text {-traumatized children } \\
\text {-abusive families and } \\
\text { problematic divorces } \\
\text {-illness and death in the } \\
\text { family } \\
\text {-children from chaotic } \\
\text { homes }\end{array}$ & $\begin{array}{l}\text {-career parents who are } \\
\text { busy and do not have } \\
\text { time for their children } \\
\text {-children who lack } \\
\text { attention and are looking } \\
\text { for affirmation } \\
\text {-concerns about family- } \\
\text { related issues } \\
\text {-children who have been } \\
\text { exposed to incest, } \\
\text { violence, or } \\
\text { misguidedness }\end{array}$ & $\begin{array}{l}\text {-parents with diagnoses } \\
\text {-parents' drug abuse } \\
\text {-conflicts at home, } \\
\text { deviant behavior, death } \\
\text { in the family } \\
\text { - quarreling parents } \\
\text {-vulnerable families, e.g., } \\
\text { low-income families or } \\
\text { ethnic families } \\
\text {-alcohol and violence }\end{array}$ \\
\hline Institutional context & -absence from school & -absence from school & & \\
\hline
\end{tabular}

\section{Types of knowledge influencing the construction of vulnerability among welfare professionals}

The ways vulnerability is perceived and handled by welfare professionals are generally influenced by the following types of knowledge: 1) knowledge and values that support the definition of the problem; 2) profession- and practice-related knowledge of how to notice and interpret signs of vulnerability; and 3) knowledge of relevant types of possible problem interventions (Abbott, 1988; Bacchi, 2009; Høybye-Mortensen, 2013; Jenkins, 1996; Jöhncke, Svendsen, \& Whyte, 2004).

Vulnerability must be observable to be experienced and articulated, initially as a concern. Indicators, expressions, or symptoms represent ways that phenomena become visible and thus are objects for observation and detection. The symptom is both part of the phenomenon and an indicator of something that extends beyond itself (Laursen, 2020). The ability to interpret aspects of the observable world as signs of a typically hidden reality can be achieved from several possible sources. The selected indicators of vulnerability used by the various professions reflect partly their work assignments and partly their professional education. Each of the four professional groups identifies its own preferences as to indicators that arouse concern for a child. 
In practice, welfare professionals often do not distinguish between signs, indicators, and causes of vulnerability among children. For example, lack of care connected to deficient nutrition, clothing, and hygiene are aspects of vulnerability that are both indicators of stress and stressful factors themselves. A child who goes to school or kindergarten without a lunch box might be interpreted as an indicator of the child's vulnerability, but it might also be considered an indicator of insufficient parental ability, which represents the real cause of vulnerability. Which aspect of the phenomenon to select as the cause of vulnerability is heavily influenced by the theories and models used by each group of professionals to structure their perceptions, which are thus generally based on professional knowledge and aspects that can be observed. This part of the problem construction draws heavily on the practice Abbott calls inference, which represents the specific know-how that characterizes the practice of the professionals (1988).

Both individual professions and the overall organization possess a set of options for intervening in typical situations of vulnerability among children. Through interdisciplinary cooperation between the administrations and between the professions involved, the various types of vulnerability included in the classification systems used are linked to sets of possible types of intervention used in the organization. The process of linking observed and classified types of vulnerability with the different possibilities of intervention is carried out on the basis of task-related work experiences and coordination tools ( $\mathrm{H} \varnothing y b y e-M o r t e n s e n$, 2013; Laursen, 2020; Sahlin-Andersson \& Engwall, 2002) provided by management.

\section{Professional background and professional tasks}

The present study has focused on the four groups of professionals that are most relevant for the implementation of the developmental strategy. Most of the similarities between these groups are obvious; all have a very explicit focus on the group of children already known by social services to be in precarious situations - in fact the same target group is described by the developmental strategy as "those who are exposed to serious threats and are in obvious danger of permanent damage" (Commune of Aalborg, 2016 p. 3) We see a somewhat more diverse picture when it comes to the other target group described in the strategy: "children and adolescents showing initial signs of being vulnerable or at risk of developing special needs" (Commune of Aalborg, 2016 p. 3).

However obvious the task of detecting vulnerability may appear, it is interpreted differently by the four professional groups. Another important observation from the interviews is the co-existence of several methods of addressing vulnerability, even if some ways of perceiving the phenomena in question are more prominent than others.

\section{Teachers and daycare workers}

An important tendency revealed in the interviews with teachers and daycare workers is that the construction of vulnerability by the two professions is influenced by their primary work 
tasks. In kindergarten, these are development, care, and learning, while for schools they are learning and teaching. The consequences are that, while daycare workers focus largely on how a child relates to other children in a social context and make observations regarding whether that child acts in conformity with social expectations, teachers in school use the notion of a "normal pupil" as their point of departure in detecting vulnerability. There is a tendency for professional employees in kindergartens and schools to classify children into dichotomies based on whether they do or do not participate adequately in the activities and social community offered by school and kindergarten, respectively. When a child deviates from the "normal child," professional employees demonstrate a pattern of trying to detect factors inherent in the child, like personality traits or developmental disorders, or trying to detect contextual factors with reference to the child's private sphere.

In general, teachers and daycare workers worry about the same aspects of the children: behavior, appearance, and ways of relating to the outside world. The identification of a problem is largely governed by the question of whether or not a child takes part in the everyday practices of the institution.

However, there are also differences between kindergartens and schools. Of course, schools have far more subject-related learning requirements than do kindergartens, and adequate behavior is also identified differently depending on a child's age. Therefore, we also observe marked differences in the disturbing features of behavior. For example, daycare workers more often referred to aspects of elementary language skills and physical and relational behavior than teachers in schools did; the latter group focused to a greater extent on school absence, children's educational performance, and disruptions of teaching.

\section{Health care workers}

Health care workers noted that they are the only professional group with access to a child's home and familial context (at least for infants under 12 months of age) as an integrated part of their professional duties. They are thus the only group who routinely enjoys a firsthand insight into a child's family background. At the same time, the essential part of their work focuses on health aspects, which is reflected in a significantly greater awareness of health problems and physical disabilities. However, all three groups of professionals have significant awareness of mental disorders as stressing factors and of the classic problems within a child's family.

\section{Social workers}

Social workers differ from the other professional groups in rarely being directly included in the early detection. They often become involved when concern for a child by a teacher, daycare worker, or health care worker has become so serious that it no longer can be handled by a professional from the general area alone. As a consequence, social workers depend on the observations of the other professions in the early detection phases. Generally, they tend to connect vulnerability to family background. Violation, abuse, mental 
illness, and a lack of resources are all prominent factors, but so are diagnoses of the children and recurring absences from school, which are classic risk factors in which social services are already involved. One social worker expressed the difference in what social workers and the general professional groups witness: "This is not a big issue. I am not worried. This is peanuts compared to what we usually experience" (SW 5). It is striking that the same issue is considered major by teachers and trivial by the social worker. Unlike the other three professions, social workers' constructions of vulnerability are related to a task-oriented combination of protecting the vulnerable child and supporting the family with the services it needs and is entitled to access.

We thus conclude that different groups of professionals tend to construct the concept of vulnerability in accordance with their professional function and work tasks in the organization. Among the four groups of professional employees, there is both a consensus regarding the traditional approach to vulnerability and differences when it comes to the interpretation of symptoms, differences that are produced by the different functions, tasks, and positions occupied by the various professions.

\section{Consequences of the different ways of constructing vulnerability}

First, the professional employees appear to construct vulnerability as a phenomenon that is largely connected to the child, either within the child (by virtue of diagnoses or behavioral expressions) or in the child's context, which is usually understood to be the family. The institutional context is not-in the professionals' eyes-a context in which vulnerability is produced. This basic assumption is common to all professional groups and makes it easy to ignore the possibility that schools and daycare arrangements like nurseries and kindergartens sometimes act as coproducers of vulnerable situations for children. To recognize the institutional context as a possible coproducer of vulnerability implies a selfcritical awareness of the ways that institutions and professional employees relate to the child (Laursen, 2020).

Second, it appears to be relatively easy for the four groups of professional employees to detect severely stressed children in vulnerable positions, especially when the causes are classic and well-known social problems of the families in question. By comparison, it appears to be much more difficult to identify vulnerability during the detection phase when the employees are confronted with an interaction between several possible causes of vulnerability; likewise, it is more difficult in this situation to choose the right decision from alternative interventions. This last challenge arises partly because detection is complicated by the different problem constructions used by various groups of professionals in interdisciplinary cooperation and partly because the inferences made by different groups of professionals cannot be unambiguously identified as indicators of vulnerability. Rather, they depend on context and the number of risk factors that must be considered in relation to a 
given concern. Finally, the situation is complicated by the different kinds of interventions that professional employees can choose to implement.

In addition, the various groups tend to interpret the same indicators differently when it comes to deciding the category of vulnerability to which an individual child should be assigned and thus assessing how serious or burdened the child's overall situation is. What is of professional concern to teachers and daycare workers is not necessarily a major concern for social workers, and vice versa. These differences between the four professions in how to interpret the indicators of vulnerability could challenge the overall coordination of the individual efforts of the four professional groups in the context of interdisciplinary task solutions.

\section{Conclusions}

The present study confirms previous research on vulnerability to the extent that vulnerability is linked by professional employees to the presence of risk factors. The risk factors selected appear to support the classic understanding of vulnerability, where the attention of professional employees is directed to elements like social exclusion, violence, sexual abuse, health difficulties (poor mental health or disabilities), stigmatization or discrimination, cultural affiliation, unemployment, and sole provider status. The detection of these risk factors addresses children and adolescents in families who present with wellknown kinds of social problems. When it comes to indicators like loneliness, social isolation, and conflicts or contextual impacts like divorce, illness, and death-indicators and symptoms that are not necessarily linked to a problematic family background-there still appears to be a greater focus on children from families with traditional problems. In sum, it appears that it is easier to act on concerns associated with this group of children rather than with children who display similar symptoms but come from families that are better off. Those families tend to be perceived as anything but vulnerable, based on the implicit understanding that, in most cases, they are capable of dealing with their problems.

Although professional employees generally do pay attention to family background when constructing vulnerability, there are also significant differences between the four professional groups when it comes to children at risk of developing special needs. Two important factors influencing the ways vulnerability is detected and constructed are the employees' professional backgrounds and, especially, their professional tasks (whether in the specialized sphere of social services or the general area where daily routines are carried out).

When constructing vulnerability, professional employees generally regard the risks responsible for creating vulnerability as related either to the child as a personal trait expressed through a certain pattern of behavior or to the child's familial context. In the present study, the professional employees tend to consider the institutional context primarily as a place where vulnerability can be detected and not as a context where it is 
produced or exacerbated. This means that there is a marked tendency to ignore schools and kindergartens as possible explanations for vulnerability.

In conclusion, we emphasize that a robust consensus on how welfare professionals should detect symptoms and make inferences about causes and link them to possible interventions would help strengthen interdisciplinary cooperation further in terms of both quality and efficiency. On the other hand, a powerful consensus also has costs in the form of possible blind spots, such as ignoring the institutional context as an arena where vulnerability might be produced.

At present, many social reforms related to vulnerable children and adolescents do not appear to have had their intended impact. One reason may be the divergent constructions of vulnerability caused by the different perspectives of the professions involved, which tend to disturb interdisciplinary cooperation and make it less effective.

\section{Article history}

Received: 27 Apr 2020

Accepted: 25 Nov 2020

Published: XX Dec 2020

\section{References}

Abbott, A. D. (1988). The system of professions: An essay on the division of expert labor. Chicago, IL: University of Chicago Press. https://doi.org/10.7208/chicago/9780226189666.001.0001

Andersen, S. H., Jensen, B., Nielsen, B. W., \& Skaksen, J. R. (2017). Hvad vi ved om udsatte unge: Historik, omfang og årsager [Knowledge on vulnerable children: History, scope and causes]. Copenhagen: Narayana Press.

Argyris, C. (1992). On organizational learning. Oxford: Blackwell.

Bacchi, C. (2009). Analysing policy: What's the problem represented to be? Frenchs Forest, NSW: Pearson Australia.

Bo, K.-A., Guldager, J., \& Zeeberg, B. (Eds.). (2015). Udsatte børn: Et helhedsperspektiv [Vulnerable children. A holistic perspecitve]. Copenhagen: Akademisk.

Brodkin, E. Z. (2012). Reflections on street-level bureaucracy: Past, present, and future. Public Administration Review, 72(6), 940-949. https://doi.org/10.1111/i.1540$\underline{6210.2012 .02657 . x}$

Catalano, R. F., Berglund, M. L., Ryan, J. A. M., Lonczak, H. M., \& Hawkins, J. D. (2002). Positive youth development in the United States: Research findings on evaluations of positive youth development programs. Prevention \& Treatment, 5(1), 98-124. https://doi.org/10.1037/1522-3736.5.1.515a 
Cingano, F. (2014). Trends in income inequality and its impact on economic growth. OECD Social, Employment and Migration Working Papers, No. 163. Paris: OECD Publishing.

Commune of Aalborg (2016). Udviklingsstrategi (Developmental Strategy). 2016-2020 https://www.aalborg.dk/usercontrols/AalborgKommune/Referater/Pdf.aspx?pdfnav $\mathrm{n}=17209704-15079809-22$.pdf\&type=bilag\&pdfid=67883

Danmarks Statistik. (2018). Udsatte børn og unge [Vulnerable children and youth]. Retrieved from https://www.dst.dk/da/Statistik/emner/levevilkaar/sociale-forhold/udsatteboern-og-unge

Eurochild. (2016). Is Europe doing enough to invest in children? Retrieved from https://www.eurochild.org/fileadmin/public/05 Library/Thematic priorities/02 Chil d Poverty/Eurochild/FINAL Eurochild Semester2016 web.pdf

Eurochild. (2017). Le bien-être des enfants: de la protection de l'enfance. Retrieved from http://www.cnape.fr/files/presse/105.pdf

European Commission. (2013). Investing in children. Retrieved from https://ec.europa.eu/social/main.jsp?catld=1060\&langld=en

Görlich, A., Pless, M., Katznelson, N., \& Graversen, L. (2019). Ny udsathed i ungdomslivet: 11 forskere om den stigende mistrivsel blandt unge [New vulnerability in life of youth]. Copenhagen: Hans Reitzels Forlag.

House of Commons - Welsh Affairs - Fifth Report. (2008).

Høyby-Mortensen, M. (2013). I velfærdsstatens frontlinje: Administration, metoder og beslutningstagning (In the front line of the welfare state: Administration, methods and decision making]. Copenhagen: Hans Reitzels Forlag.

Inchley, J., \& Currie, D. (2016). Growing up unequal: gender and socioeconomic differences in young people's health and well-being: International report from the 2013/2014 survey. Copenhagen: WHO Regional Office for Europe.

https://www.euro.who.int/ data/assets/pdf file/0003/303438/HSBC-No.7Growing-up-unequal-Full-Report.pdf

Jenkins, R. (1996). Social Identity. New York, NY: Routledge.

Jöhncke, S., Svendsen, M. N., \& Whyte, S. R. (2004). Sociale teknologier som antropologisk arbejdsfelt [Social technologies as an anthropological field of work]. In K. Hastrup (Ed.), Viden om verden: En grundbog i antropologisk analyse (pp. 385-408). Copenhagen: Hans Reitzels Forlag.

Kvello, $\varnothing$. (2013). Børn i risiko [Children at risk]. Copenhagen: Samfundslitteratur.

Lakoff, G. (1987). Women, fire and dangerous things: What categories reveal about the mind. Chicago, IL: University of Chicago Press.

Laursen, E. (2020). Sociale teknologier og samarbejde om udsatte børn og unge [Social technologies and cooperation on vulnerable children and youth]. Aalborg: Aalborg Universitetsforlag.

Lipsky, M. (2010). Street-level bureaucracy: Dilemmas of the individual in public services ( $30^{\text {th }}$ anniversary ed.). New York, NY: Russell Sage Foundation. 
Mynarska, M., Riederer, B., Jaschinski, I., Krivanek, D., Neyer, G., \& Oláh, L. (2015). Vulnerability of families with children: Major risks, future challenges and policy recommendations. European Union Families and Societies Working Paper Series 49. Retrieved from http://www.familiesandsocieties.eu/wpcontent/uploads/2015/11/WP49MynarskaEtAl2015.pdf

National Association of Municipalities. (2019). Nøgletal udsatte børn [Key figures vulnerable children]. (2019). KL's nøgletalspublikation 2019.

$\emptyset$ stergaard Møller, M. (2018). Styring, professionel dømmekraft og faldgruber for fagprofessionel værdiskabelse [Control, professional jurisdiction and pitfalls for professional value creation]. Tidsskrift for Professionsstudier, 14 (26), 86-97.

Pratt, M. G. (2008). Fitting oval pegs into round holes. Organizational Research Methods, 11(3), 481-509.

Rambøll Management Consulting. (2016). Viden om risiko- og beskyttelsesfaktorer for børn og unge i udsatte familier [Knowledge about risk- and protective factors for children and young people in at risk families]. Retrieved from https://socialstyrelsen.dk/udgivelser/ny-udgivelse-kortlaegger-risiko-ogbeskyttelsesfaktorer-for-born-og-unge-der-har-sociale-problemer-taet-inde-pa-livet

Rubington, E., \& Weinberg, M. (1969). New York, NY: The Macmillan Company

Sahlin-Andersson, K. \& Engwall,L. (2002). The expansion of management knowledge: Carriers, flows and sources. Stanford, CA: Stanford University Press.

Schoon, I. (2006). Risk and resilience. Cambridge: Cambridge University Press.

Socialstyrelsen. (2011). Håndbog om Barnets Reform: - Viden til gavn. Socialt udsattes situation ÅRSRAPPORT. (2019). Retrieved from https://www.udsatte.dk/dyn/resources/Publication/file/7/107/1566115789/endelig udsatte-aarsrapport 2019 30-web.pdf

Theilmann, B. (2020). Interdisciplinary cooperation in the field of measure, means and methods: A challenge to welfare professionals. Nordic Social Work Research. https://doi.org/10.1080/2156857X.2020.1724188

Zacka, B. (2017). When the state meets the street: Public service and moral agency. Cambridge, MA: Harvard University Press. https://doi.org/10.4159/9780674981423 